\title{
URBANI MENADŽMENT I UPRAVLJANJE ŽIVOTNOM SREDINOM U GRADU U USLOVIMA PERMANENTNOG INTENZIVIRANJA SAOBRAĆAJA
}

Predrag Mihajlović ${ }^{1}$

Ljiljana Stošić ${ }^{2}$

UDK: $502.131 .1: 711.16: 656.1$

DOI: 10.14415/konferencijaGFS 2016.097

Rezime: Intenzivni tehničko-tehnološki, privredni $i$ društveni razvoj, porast broja stanovnika, ubrzani tempo života i niz drugih faktora, pored dobrobiti koje donose žiteljima, imaju negativan efekat na održivi razvoj gradova sa stanovišta neophodnosti upravljanja $i$ zaštite životne sredine u gradu. U tom kontekstu saobraćaj ima posebnu ulogu. Pored svih svojih dobrih strana i pozitivnih privrednih i društvenih efekata, on predstavlja najvažniji činilac koji negativno utiče na životnu sredinu grada. Brojni podaci o unutrašnjem gradskom saobraćaju, ukazuju na sve veći priliv saobraćaja $i$ saobraćajna zagušenja u gradovima. Zato se logično nameće potreba za širenjem postojećih saobraćajnica $i$ novih parking-prostora $i$ to, po pravilu na štetu zelenih površina, što uz sve veću buku i aero-zagađenje ugrožava životnu sredinu u gradu koja je najvažniji uslov održivog razvoja grada. Potreban je pravilan integrisan pristup svih činilaca koji mogu pomoći u kreiranju i vođenju urbane $i$ ekološke politike, koja će svojim upravljačkim delovanjem dovesti do stvaranja neophodnih uslova za smanjenje zagađenja koja su prvenstveno posledica saobraćajnih tokova.

Ključne reči: Urbani menadžment, menadžment životnom sredinom, saobraćaj, održivi razvoj grada

\section{UVOD}

U upoređenju sa živim bićima, saobraćaj u gradskoj sredini predstavlja krvotok tog gradskog organizma, što govori o važnosti saobraćaja kao jedne od glavnih privrednih grana u gradu. Sredinom XX veka, kada je počela ekspanzija automobila, na planeti Zemlji je živelo 2,6 milijardi ljudi koji su posedovali oko 50.000.000 automobila. U novom milenijumu 6 milijardi ljudi procenjuje se da raspolaže sa preko 500.000.000 automobila (sa teretnim vozilima i motociklima čak više od 800 miliona). U ovom periodu populacija je udvostručena, dok je broj automobila porastao za 10 puta. Imajući u vidu da se u svetu godišnje proizvodi oko 50 miliona vozila, očekuje se da će za dve decenije u svetu biti oko milijardu putničkih automobila. Stepen motorizacije je

\footnotetext{
${ }^{1}$ Dipl.ing.arh, Republički urbanistički inspektor, Ministarstvo građevinarstva, saobraćaja i infrastrukture R Srbije, predrag.mihajlovic@gsi.gov.rs

${ }^{2}$ Doktor ekonomskih nauka; Doktor menadžmenta, VŠPSS, Vranje, mihajlovicp@ptt.rs
} 
Contemporary achievements in civil engineering 22. April 2016. Subotica, SERBIA

pokazatelj broja putničkih automobila na 1.000 stanovnika ili broja stanovnika na jedno putničko vozilo. U razvijenom svetu pokazuje tendenciju ekspanzivnog rasta sve do okvirnog odnosa 350-400 PA/1.000 stanovnika ili 2,8-2,5 stanovnika/PA. Takav stepen motorizacije približno odgovara nacionalnom dohotku od oko 7.5000 US \$/stanovniku. Danas je nezamislivo funkcionisanje aktivnosti u gradu bez saobraćaj i adekvatne saobraćajne infrastrukture. Pored pozitivnih primarnih efekata koji se odnose na nesumnjivo snažan uticaj na društveni, ekonomski, privredni, kulturni, sportski i sveopšti razvoj, saobraćaj ima i vrlo negativan efekat na životnu sredinu i održivi razvoj grada. [1] Saobraćaj u urbanoj sredini predstavlja izvor najvećeg zagađenja vazduha, čak istraživanja pokazuju da u ukupnom atmosferskom zagađenju saobraćaj učestvuje sa preko 50\%. Emisija olova, azotnih oksida, ugljendioksida, sumpor-dioksida i taložnih čestica na pojedinim lokalitetima u gradu dostiže kritičnu tačku i preti sve većem ugrožavanju ljudskog zdravlja, u uslovima kada broj vozila defiluje gradskim ulicama. Pored toga, buka je potencijalno najopasniji zagađivač. U zemljama članicama OECD-a, oko 130 miliona ljudi je izloženo buci od preko $65 \mathrm{~dB}(\mathrm{~A})$, što predstavlja $1 / 5$ ukupnog stanovništva tih zemalja, a skoro $1 / 2$ stanovništva se nalazi u tzv. sivoj zoni gde je nivo buke od 55 do $65 \mathrm{~dB}$ ). Potencijalno veliku opasnost za grad predstavlja i prevoz opasnih materija gradskim ulicama, što u slučaju saobraćajnih nezgoda može izazvati vrlo negativne ekološke efekte i izazvati nesagledive posledice po životnu sredinu u gradu i šire. U ovom radu je stavljen akcenat na uticaj saobraćajnih tokova na održivi razvoj gradova uopšte, i data su neka od mogućih rešenja u sistemu upravljanja saobraćajem u cilju očuvanja ekoloških parametara i održivog razvoja grada.

Ekonomski razvoj gradova neminovno povećava obim kretanja svih vrsta, kao rezultat potrebe za adekvatnom pristupačnošću i neograničenom mobilnošću stanovnika. Ovo pogoršava odlike okruženja i problemi koji se moraju rešiti, dobijaju i novo značenje, tako da se razvoj saobraćaja u gradovima usmerava u tri osnovna pravca: unapređuje se postojeća praksa (planiranje namene površina i upravljanja saobraćajem i podsticanje alternativnih vrsta prevoza); definiše se nova politika urbanog ubrzanog razvoja (što manji obim putovanja, prevoz manje zavistn od automobila); primenjuje se koncept održivog razvoja (kao sveobuhvatna strategija uklapanja saobraćaja u okvire poželjne životne sredine u gradovima). [2]

\section{BUKA I AEROZAGAĐENJE U URBANOJ SREDINI I OPTIMIZACIJA SAOBRAĆAJA SA ASPEKTA ZAŠTITE ŽIVOTNE SREDINE}

Kada je reč o Srbiji, prosečna starost naših vozila je preko 12 godina, koja u velikom broju za svoj pogon koriste ekološki štetna goriva. Posledice prisustva sumporovih i azotnih oksida u biosferi dostižu zabrinjavajuće razmere. Najveći zagađivači atmosfere su motorna vozila koja koriste motorne benzine koji u svom sadržaju kao aditiv imaju jedinjenja olova (tetrametil ili tetraetilolovo) i vozila koja za svoj pogon koriste dizel gorivo sa velikim primesama sumpora. Zagađenom vazduhu naših velikih gradova doprinosi loš kvalitet goriva. [3] Količina sumpora u dizel gorivu je 20 puta veća (1 prema $0,05 \%$ težinskih/l) a oslobođeni sumpor-dioksid može se oksidisati do sulfata $u$ zemljištu, redukovati do sulfata u atmosferi ili oksidovati u atmosferi kao sumporna 
kiselina, koja predstavlja glavnu komponentu "kiselih kiša". [4] Na povećan sadržaj ove dve, po zdravlje i okolinu izuzetno opasne materije, nadovezuju se i emisije čvrstih čestica karakteristične za nepotpuno sagorevanje goriva $u$ istrošenim motorima. Činjenice pokazuju da je emisija gasova iz izduvnih sistema motornih vozila u centralnom gradskom delu (kod svih gradova) dosta povećana i izmerene su količine znatno veće umesto $3 \mathrm{mg} \mathrm{CO}$ po $\mathrm{m}^{3} / \mathrm{god}$ koliko je pozitivnim propisima dozvoljeno. Postoje još neki izvori zagađivanja koji su povezani sa auto-saobraćajem. Velika količina čestica nastaje trenjem i habanjem automobilskih guma i putne podloge. Ogromne količine iskorišćenih auto-guma u mnogim zemljama predstavljaju problem koji traži hitno rešavanje.

Saobraćajna buka kao zagađivač ima vrlo visok udeo u štetnim ekološkim efektima po urbanu sredinu. Primera radi, usamljen putnički automobil pri brzini kretanja od $35 \mathrm{~km} / \mathrm{h}$ izaziva buku od oko $50 \mathrm{~dB}$, a pri brzini od $75 \mathrm{~km} / \mathrm{h} 59 \mathrm{~dB}$, a usamljeno teretno vozilo pri brzini od $40 \mathrm{~km} / \mathrm{h}$ izaziva buku nivoa od $76 \mathrm{~dB}$. [5] Prema tome, kako je buka najveća u ulicama centralnog dela grada najbolje je rešenje da se saobraćaj izmesti iz centralnog dela grada i da se prevoz obavlja samo vozilima javnog prevoza sa ograničenom brzinom kretanja. Pri projektovanju novih saobraćajnica, saobraćajnih čvorova i parkirališta neophodno je zadovoljiti kriterijum da dnevni nivo buke ne bude veći od od $65 \mathrm{~dB}(\mathrm{~A})$. [5] Ublažavanje dejstva buke je moguće zasadom visokog zelenog rastinja kao i postavljanjem zaštitnih izolatornih barijera ( naravno, gde je to moguće).

Tabela 1. Toksikološka slika zagađenja urbane sredine

\begin{tabular}{|l|l|l|}
\hline Zagađivač & Samostalni uticaj & Kombinovano dejstvo \\
\hline As & Arsenic dermatitis & - \\
\hline Azbest & Azbestosis mesotheliuma & \multicolumn{1}{|c|}{-} \\
\hline $\mathrm{Be}$ & Berylliosis & Be+F, plućne bolesti \\
\hline $\mathrm{CO}$ & Trovanje krvi & Sinergetski s CO2, O3, pO2 depresija \\
\hline $\mathrm{F}$ & Fluorosis & Ubrzava efekte na organe čoveka \\
\hline Prašina & Oštećenje pluća & $\begin{array}{l}\text { U kombinacijama s mikroorganizmima, plućne } \\
\text { bolesti }\end{array}$ \\
\hline $\mathrm{Pb}$ & $\begin{array}{l}\text { Trovanje s teškim } \\
\text { metalima }\end{array}$ & U kombinaciji s metalima deluje sinergetski \\
\hline NO, NO2 & Kancerogen & Sinergetsko delovanje s mikroorganizmima \\
\hline Ozon & Oštećenje pluća & Sinergetski s mikroorganizmima, tumor \\
\hline SO2, SO3 & Oštećenje pluća & SO2, SO3, sinergetski deluju na pluća \\
\hline
\end{tabular}

Saobraćaj u našim gradovima doživljava sve veću ekspanziju kao posledicu ubrzanog tehnološkog, privrednog, ekonomskog i kulturnog razvoja. Saobraćajnice i gradske ulice su projektovane za daleko manji broj vozila i građene su po urbanističkim planovima koji nisu predvideli tako brzu ekspanziju saobraćaja. Pravljenje novih saobraćajnica je u postojećim okolnostima gotovo nemoguće, a i eventualno proširene pojedinih saobraćajnica iziskuje ogromna materijalna ulaganja i promenu izgleda makro i mikro strukture grada. Potreba za kretanjem gradom je sve veća i u stalnom je porastu. Uglavnom, sva kretanja se obavljaju transportnim sredstvima. Saobraćajni sistemi su izloženi sve većem pritisku i na granici su izdržljivosti. Saobraćajne gužve u gradu postaju jedan od glavnih opterećujućih infrastrukturnih problema grada. Kao sekundarni, 
Contemporary achievements in civil engineering 22. April 2016. Subotica, SERBIA

vrlo negativan efekat je sve veće zagađenje i ugroženost životne sredine. Podaci o saobraćajnim tokovima na putnoj mreži u koje spada i PGDS služe kao baza za donošenje odluka o razvoju, planiranju i eksploataciji putne mreže kao i jedan od osnovnih parametara u operativnom upravljanju saobraćajnim tokovima. PGDS je sastavni deo informacione osnove baze podataka o putnoj mreži. [6]

\section{MERE UNAPREĐENJA UPRAVLJANJA ŽIVOTNOM SREDINOM U GRADU U USLOVIMA PERMANENTNOG INTEZIVIRANJA SAOBRAĆAJA}

Saobraćaj je uzrokovanjem velikog broja negativnih eksternih efekata sa velikim posledicama, ukazao na neodlučnu potrebu da se u razvojne i tekuće programe uključi i analiza eksternih efekata. Zato se pristupilo pokušaju da se negativne posledice koje uzrokuje saobraćaj identifikuju, kvantifikuju i naplate, s ciljem preuzimanja odgovarajućih akcija koje će da utiču na smanjenje tih efekata. Problem operacionalizacije ovih efekata javlja se zbog toga sto nastaje u netržišnim oblastima, teško ih je definisati, vrednovati i naplatiti kroz određene ekonomske mehanizme. Teorija i praksa traže određena rešenja u ovoj oblasti da bi se izbegle paušalne procene, zloupotrebe i aproksimacije, koje se koriste prema potrebi uz uglavnom površna objašnjenja. Uslovi eksploatacije vojnih motornih vozila su specifični u odnosu na uslove rada vozila u civilnom saobraćaju, ali je evidentno postojanje eksternih efekata, odnosno troškova. Zbog toga je potrebna analiza eksternih efekata pri realizaciji transportnih zadataka koji će uključivati i mere minimizacije eksternih efekata u skladu sa savremenim tendencijama nauke i prakse. Neophodno je kroz primenu tehničkih standarda i propisa, primenu poreske i investicione politike i primenu odgovarajućih organizacionih mera uticati na smanjenje eksternih efekata saobraćaja. Zabrinjavajuća je činjenica da su ugroženi ekološki parametri koji odslikavaju opšte stanje u životnoj sredini. Za održivi razvoj grada neophodno je definisati mere ekološke politike koja će sadržati upravljačke elemente koji integrišu sve bitne činioce u funkcionisanju saobraćajnog sistema grada u uslovima intenziviranja saobraćaja. Potrebno je ograničiti uticaj infrastrukturnog razvoja na korišćenje zemljišta, smanjiti gustinu saobraćaja i preopterećenost puteva (naročito u najurbanijim rejonima), eliminisati ili smanjiti rizik pri prevozu opasnih ili otpadnih materija.[6] Mere koje se mogu primeniti na nepovoljnu ekološku sliku grada zahtevaju integrisan pristup i radikalna rešenja u vođenju ekološke politike. Neka od mogućih rešenja su:

1. Restriktivni prilaz određenim (centralnim) delovima grada motornim vozilima.

2. Stimulisanje korišćenja vozila javnog gradskog prevoza.

3. Favorizacija upotrebe vozila sa većim stepenom ekoloških performansi.

4. Reorganizovati gradski teretni saobraćaj, sa inicijativom za apsolutno izmeštanje iz užeg gradskog jezgra.

5. Nove mere u vođenju gradskih parkirališta.

6. Veći nivo kontrole prevoza opasnih materija i iznalaženje rešenja da se ovaj transport izmesti sa gradskih ulica.

Ovde je daleko važnije, umesto taksativnog nabrajanja potrebnih akcija koje mogu isto tako predstavljati skup želja, skrenuti pažnju na ono ključno: nova politika zaštite 
životne sredine u konceptu "održivog" razvoja može se realizovati samo usklađenim delovanjem državnih organa na svim nivoima, naučnih i stručnih asocijacija, preduzeća, uključena u sistem prevencije i zaštite. Istovremeno, uz pomenute principe odgovornosti i nadležnosti, potrebno je imati i kritični stav u odnosu na stvarne domete pojedinih metoda i tehnika.

\subsection{Restriktivni prilaz centralnim delovima grada motornim vozilima.}

U složenoj gradskoj strukturi, saobraćaj se pojavljuje u tri oblika: kroz uličnu mrežu, brojnošću motornih vozila i kretanjem vozila kroz urbanu sredinu. Putna i ulična mreža preko funkcionalne i fizičke klasifikacije, a na osnovu savremenih urbanističkosaobraćajnih postavki i planersko-projektantskih zahteva deli se na primarno-putnu mrežu (autoputevi, magistrale, saobraćajnice, sabirne ulice) i sekundarnu-putnu mreću (pristupne ulice, parkirališta, trotoari, pešački prelazi). Primarna mreža namenjena je protočnom saobraćaju, a sekundarna omogućuje prilaz do određenih ciljeva. Osnovni problem u većini gradova je što nasleđeno stanje ulične mreže ne zadovoljava po poprečnom profilu, trasi, ni po izgrađenosti. Zbog toga primarna mreža nema dovoljne kapacitete da prihvati tokove iz sekundarne mreže u kritičnim časovima, posebno kada je pitanju transport opasnog tereta. Negativni uticaji koje prouzrokuje saobraćaj nazivaju se negativnim eksternim efektima: saobraćajne nezgode, zagušenja u saobraćaju, zauzimanje površina, buka, izduvni gasovi, nekontrolisano oslobađanje štetnih i opasnih materija, posebno u akcidentnim situacijama. Restriktivni prilaz putničkog a pogotovu teretnog saobraćaja centralnim zonama grada mora biti jedna od najznačajnijih aktivnosti u vođenju gradske saobraćajne politike. Grad kao administrativni, kulturni, trgovinski i ekonomski centar trpi enormna saobraćajna opterećenja u svojoj urbanoj zoni. Dolazi vrlo često do saobraćajnih zagušenja pa i saobraćajnog kolapsa. Emisija izduvnih gasova i saobraćajna buka ozbiljno ugrožavaju život u gradu. Ove mere se već primenjuju u mnogim evropskim gradovima i dale su odlične rezultate. Treba uzeti u obzir da ove mere ipak treba primeniti na manji deo grada, tj. na samo srce grada (centralnu zonu), jer bi se u tom slučaju mogla izvršiti pravilna optimizacija saobraćaja u gradu.

\subsection{Stimulisanje korišćenja vozila javnog gradskog prevoza}

Favorizovanje korišćenja vozila javnog gradskog prevoza je jedan od imperativa ukoliko se žele postići pravi efekti vođenja saobraćajne ekološke politike. Poznato je da je u gradu velika cirkulacija putnika. Najveći broj učesnika u saobraćaju je u jutarnjim i popodnevnim časovima, kada građani odlaze i vraćaju se sa svojih radnih mesta. U tim "saobraćajnim špicevima" je neophodno maksimalno pojačati gradski javni prevoz i na taj način destimulisati korišćenje sopstvenih vozila za odlazak na posao. Činjenica je da autobusi javnog prevoza predstavljaju velike izazivače saobraćajne buke i emisije štetnih gasova, ali mora se uzeti u obzir činjenica da jedan gradski autobus supstituiše 40-60 putničkih automobila. Imajući to u vidu sa ekološke strane, gradski prevoz dobija apsolutnu prednost u odnosu na individualna putnička vozila. Nažalost, naši gradovi u svom gradskom voznom parku najčešće ne poseduju i vozila koja za pogon imaju 
Contemporary achievements in civil engineering 22. April 2016. Subotica, SERBIA

elektromotore (tramvaje i trolejbuse). Dugoročna saobraćajna politika grada treba da se upravo osloni na ova vozila, kao i na izgradnju lakog šinskog metroa, što bi u perspektivi, i uz primenu ostalih ekoloških mera doprinelo podizanju kvaliteta vazduha $u$ gradu.

Obzirom da je ulična mreža u mnogim gradovima preopterećena putničkim automobilima, neophodno je selektivno korišćenje ovih vozila. To pre svega znači destimulisanje vlasnika putničkih vozila od upotrebe vozila na odlazak i povratak s posla, što se moće postići bitnim poboljšanjem usluga javnog gradskog prevoza. Kolektivni prevoz putnika pruža podjednaku šansu za ostvarenje putovanja svakom stanovniku grada. Javni gradski prevoz traži dobru uličnu mrežu, uređena stajališta i odgovarajuće prostore za organizaciju održavanja voznog parka. Vozila javnog gradskog putničkog prevoza angažuju svega $10 \%$ gradski prostora, a u isto vreme obavljaju najveći transportni rad u prevozu ljudi (preko 50\%). Za objektivno utvrđivanje uticaja vozila javnog gradskog prevoza na zagađivanje životne sredine, neophodno je kao jediničnu meru odrediti transportni rad (putnik/km) tako da se dobije zbirni pokazatelj količine aerozagađenja i transportnog učinka. Mali transportni učinak i velika gustina tokova putničkih automobila sugerišu da je osnovni uzročnik problema aerozagađenja, masovno prisustvo individualne motorizacije, a ne vozila površinskih vidova javnog gradskog prevoza.

Imajući u vidu činjenicu da putničko vozilo u gradu ima prosečnu potrošnju goriva od 12 $1 / 100 \mathrm{~km}$, može se izračunati da jedan putnički automobil na pređenih $100 \mathrm{~km}$ izbaci 3290 g CDO, dok autobus pri prosečnoj potrošnji goriva od $40 \mathrm{l} / 100 \mathrm{~km}$ izbaci u atmosferu $284 \mathrm{~g}$ CO. Prema tome jedan putnički automobil izbaci CO kao 12 autobusa. Ako se pođe od činjenice da jedan autobus u gradu prevozi 80-90 putnika, a putnički automobil oko 1,5 putnika, tada je potrebno oko 60 putničkih automobila da bi prevezli putnike jednog autobusa, pri čemu putnički automobil za isti transportni rad izbace 700 puta više CO od jednog autobusa.

Poseban je problem u akcidentnim situacijama u vazdušnom, rečnom, drumskom i železničkom saobraćaju i transportu opasnih materijala i tereta. Situacija sa čvrstim materijama je drugačija, odnosno na 100 pređenih kilometara putnički automobil izbaci $170 \mathrm{~g}$, a autobus $520 \mathrm{~g}$ čvrstih materija. Dakle, jedan autobus izbaci u atmosferu čvrstih materija kao 30 putničkih automobila. Za isti transportni rad putnički automobili izbace dva puta više čvrstih materija od jednog autobusa, tim pre, što u čvrstim materijama ima veliki procenat kancerogenih materija koje imaju vrlo nepovoljno dejstvo na zdravlje ljudi.

U svetu pridaje se različit značaj uticaju javnog gradskog prevoza na zaštitu životne sredine. Iako se ni jedan sistem, po pravilu, ne odbacuje iz ekoloških razloga, trebalo bi razmotriti vrednost svakog mogućeg sistema u smanjivanju ekoloških uticaja.

\subsection{Upotrebe vozila sa većim stepenom ekoloških osobina}

Rast saobraćaja u visoko razvijenim industrijalizovanim zemljama postepeno opada. U OECD-u predviđaju ovo opadanje do 2\%. Predviđanja za narednih 4-5 decenija nisu optimistička. Ekonomija potrošnje goriva i smanjenje emisije izduvnih gasova je prodoran proces, s obzirom da manja potrošnja goriva podrazumeva, manju emisiju i intenzitet buke. Pored stroge kontrole emisije i značajnijeg poboljšanja ekonomije 
goriva, globalno zagađenje vazduha će ponovo početi da raste od 2010. godine. Višegodišnja dostignuća u proizvodnji čistih motora i smanjenju emisije izduvnih gasova biće ozbiljno narušena povećanjem broja automobila i broja putovanja.

Upotreba vozila sa kvalitetnim ekološkim karakteristikama mora biti jedan od državnih prioriteta i vođenju saobraćajne politike. Jedan od zanimljivih primera je Francuski grad Rošel.

Naime, gradske vlasti ovog turističkog, istorijskog i univerzitetskog centra suočene sa saobraćajnim kolapsom, bukom i štetnim gasovima još pred desetak godina odlučile su da preduzmu jednu zanimljivu inovativnost. Došli su na ideju da nabave određenu količinu automobila na električni pogon koji će biti u vlasništvu grada i koje će moći koristiti svi žitelji koji se pretplate na mogućnost njihovog korišćenja. Za početak je nabavljeno stotinak manjih vozila. Napravili su specijalnih šest parkinga u gradu za ova vozila i svako od pretplatnika mogao je parkirati vozilo na koji parking želi. Ako mu ponovo zatreba auto, ode do prvog parkinga i proverom boje na staklu vozila ustanovi da li se auto puni, da li je zauzet ili je slobodan.

Ceo ovaj sistem je vrlo jeftin i košta korisnike oko 80 evra mesečno. Cilj projekta je smanjenje privatnih automobila u užem gradskom jezgru. No ovakvi sistemi za sada teško mogu zaživeti jer je automobilska industrija globalno gledano još nespremna na ovakve i veće poduhvate, dok je i dalje profit od fosilnih goriva jedan od najunosnijih svetskih biznisa.

U našim uslovima treba favorizovati pored vozila na električni motorni pogon (u gradskom saobraćaju) i vozila koja za pogon koriste tečni naftni gas. Ovo gorivo višestruko manje zagađuje atmosferu i kao takvo mora biti jedan od vodećih energenata u ovom veku.

\subsection{Reorganizacija gradskog teretnog saobraćaja, sa inicijativom za njegovo izmeštanje iz užeg gradskog jezgra}

Teretna vozila, širokog spektra nosivosti, zadovoljavaju egzistencijalne transportne potrebe grada, počev od snabdevanja životnim namirnicama i energijom do prenosa pošte i drugih materijala. U prostornom smislu, teretna vozila kreću se uličnom i putnom mrežom, a istovar i utovar obavljaju na "stanicama" koje su trajno formirane i građene za ovu namenu ili na prostorima koji se samo u određeno vreme koriste za pretovar (privremena parkirališta, trotoari, pešačke staze, delovi kolovoza).

Pored ovih prostornih zahteva, teretna vozila traže prostore za organizaciju auto baza i mesta za njihovo mirovanje, kada se ne koriste za transport. Teretno vozilo proizvodi buku kao 8 do 10 putničkih automobila. Reorganizovati gradski teretni saobraćaj, sa inicijativom za njegovo apsolutno izmeštanje iz užeg gradskog jezgra je zahtev koji je prioritetan.

Prema podacima PGDS, teretni saobraćaj značajno opterećuje saobraćajnu infrastrukturu grada $\mathrm{i}$ učestvuje u ukupnoj strukturi saobraćaja od 10 do $15 \%$. Jedna od mera je svakako potpuna zabrana kretanju teretnog saobraćaja kroz grad, izuzimajući komunalne službe, javni prevoz i vozila prioriteta.

Istovremeno potrebno je obezbediti što više alternativnih pravaca za nesmetano odvijanje teretnog saobraćaja i preusmeravanja tranzitnog saobraćaja. [7] 
Contemporary achievements in civil engineering 22. April 2016. Subotica, SERBIA

\subsection{Nove mere u vođenju gradskih parkirališta}

Sa aspekta eksternih efekata saobraćaja, važna je saobraćajna politika u celini, kao konzistentan skup mera koji usmerava razvoj i funkcionisanje saobraćaja u željene okvire. Specifične mere koje su od najvećeg značaja s aspekta ekologije se, u slučaju saobraćaja, odnose na standarde kojih se moraju pridržavati proizvođači vozila i delova, kao i oni koji investiraju ili eksploatišu saobraćajnu infrastrukturu (železnica, putna privreda, aerodromi, sidrišta). [8] Sa povećanjem saobraćaja u gradu neminovno dolazi i do potrebe za većim brojem parking prostora. Da bi se izgradila nova parkirališta moraju se nasilno uklanjati zelene površine, parkovi i drvoredi. Ovo svakako ne ide u prilog ekološkoj situaciji u gradu i ne sme se dozvoliti da to bude ceh u izgradnji nove saobraćajne infrastrukture. Bez izuzetka, naši gradovi su prilično deficitarni sa brojem parking mesta u svom centralnom delu, i pored novih javnih garaža i nesumnjivog truda gradskih vlasti da se ovaj hronični problem gradova što više ublaži, nameće se potreba za uvođenjem restriktivnih mera. Jedna od mogućih fiskalnih mera je naplata takse vozilima koja saobraćaju kroz gradsko jezgro. [9] Ova nepopularna mera je doprinela izbegavanju saobraćajnog kolapsa u nekim svetskim metropolama (Singapur). U centralnom delu grada cena parkiranja mora biti višestruko veća u odnosu na obodne delove i na taj način destimulisati kretanje vozila centrom grada, i konačno moguće je i uvođenje još jedne isto tako nepopularne mere kao što je tzv. par-nepar kretanja kroz grad.

\subsection{Kontrola i praćenje prevoza opasnih materija u gradu}

Pored tehničkih inovacija na motorima, primene kvalitetnijih izvora energije, stroge kontrole emisija, strožih standarda kvaliteta vazduha, neophodno je preduzimati mere za ograničavanje upotrebe prevoza opasnih materija u gradu. Podizanje nivoa kontrole i praćenja prevoza opasnih materija i iznalaženje rešenja da se ovaj transport izmesti sa gradskih ulica je takođe prioritetan zadatak. Iako je propisima strogo regulisano kako, kada i na koji način je moguće transportovati opasne materije, uočeni su problemi u transportu, koji ne tako retko rezultiraju incidentima koji prestavljaju ogromnu ekološku opasnost za grad. [10] Ovi problemi se pre svega odnose na nepoštovanje propisa $u$ transportu i neodgovornosti lica koji se bave ovim prevozom, neophodno je apsolutno i dosledno poštovanje svih propisanih mera u transportu opasnih materija. Usled nestručnog rukovanja vozilom, grešaka i nepažnje, neprimerenoj vožnji ,pri prevozu može doći do neželjenih situacija, koje utiču direktno na zagađenje životne sredine, kao što su: prolivanje tečnosti, požari i eksplozije, trovanje, uništenje imovine i opasnosti po ljudske živote.[11] Iz ovoga proističe da je potrebno stručno osposobljavanje svih lica koja učestvuju u procesu utovara i prevoza opasnih materija. Propusti i nedostaci se mogu javiti i kod organa koji daju saglasnosti za transport opasnih materija, sistemu kontrole transporta opasnog materijala, kao i samom obeležavanju vozila koja vrše transport. Kontrolu transporta opasnih materija moraju obavljati obučena stručna lica uz asistenciju saobraćajne policije, na zato određenim specijalnim parkinzima. Ti parkinzi moraju biti van naseljenog mesta, da ta vozila mogu biti tu privremeno zaustavljena $u$ slučaju potpune kontrole transporta opasnog tereta. 


\section{ZAKLJUČAK}

Sve veća koncentracija u urbanim sredinama i prometni saobraćaj (putnički, teretni, vojni) ima sve više za posledicu - ugrožavanje radne i životne sredine. Uticajni faktori su: zagađenje vazduha i objekata, buka i vibracije, saobraćajne nezgode i udesi, nekontrolisano ispuštanje štetnih i opasnih materija, saobraćajno zagušenje i metež. U urbanim sredinama posebno je loše stanje ulične mreže, neadekvatna organizacija javnog prevoza i transporta, nepoštovanje saobraćajne kulture, tehnički neispravna vozila i porast broja vozila u saobraćaju. [12] Osnovni izvor zagađenja u gradu je svakako proizveden na gradskoj putnoj mreži. Zbog toga, kao osnovne izvore emisije zagađivača vazduha i životne sredine na putnoj mreži treba smanjiti saobraćajne tokove, tj. smanjiti štetne efekte definisane kao zbir prosečnih emisija svakog pojedinačnog vozila. Zagađenje koje koje nastaje kao posledica saobraćaja zavisi od uslova saobraćaja na mreži, odnosno od nekih od osnovnih parametara, kao što su broj vozila, brzina i gustina saobraćaja kao i strukture vozila. Kvalitet organizacije javnog putničkog prevoza u gradu, odnosno nivou usluge koji on pruža, najviše utiče na ostvarenje želja za putovanje putničkim automobilom ili javnim gradskim prevozom, a time i na kvalitet životne sredine u gradu. Osobenosti saobraćajnog toka koje uključuju stanja vozila i opšte uslove odvijanja saobraćaja su takođe bitni činioci od kojih zavise ekološki parametri u gradu. Kreiranje i vođenje ekološke politike u gradu kroz primenu zakonske regulative i integrisani pristup svih bitnih činilaca može dovesti do bitnog poboljšanja ekoloških parametara u gradu.

\section{LITERATURA}

[1] Blagojević, A.: Menadžmentu u saobraćaju se mora dati veći značaj, „Novi horizonti“, Saobraćajni fakultet, Doboj, 2013

[2] Dewar, R.E., Olson, P.L.: Human Factors in Traffic Aafety, Lawyers \&Judges Publisging Company, Inc, 2014

[3] D. Bajin: "Saobraćaj u gradovima - stanje, trendovi, perspektive, Konferencija Ekološki problemi gradova, Beograd, 2004.

[4] M. Bajić-Brković "Mogu li kreativne ekonomije da proizvode održiva rešenja? neka evropska iskustva" Arhitektura I urbanizam, br.24-25, str. 47-60

[5] M. Vuković: "Osnovi ekologije", Tehnički fakultet u Boru, 2005.

[6] M. Đukanović: "Ekološki izazov", Elit, Beograd,1991.

[7] Brojanje saobraćaja na putevima Republike Srbije, Republička Direkcija za puteve, Beograd.

[8] L. Jovanović - Kolomejceva: "Ekološki menadžment”, Alfa Univerzitet, Beograd, 2004.

[9] K. Cox: "The local and the global in the new urban politics: A critical view. Environment and Planning, 1993., p.433-448

[10] V.Jovanović: "Zone ekološkog uticaja saobraćaja”, Ecologica 12, 2005.

[11] Olson, P.:"Forensic Aspects of Driver Perception and Response", Eugene Farber, Judges Publisging Company, Inc.: 2010 
Contemporary achievements in civil engineering 22. April 2016. Subotica, SERBIA

[12] Lj. Stošić, S. Đurić: “Održivost prostornog razvoja Srbije”, Održivi prostorni razvoj gradova, IAUS, Beograd, 2008.

\section{URBAN MANAGEMENT AND ENVIRONMENTAL MANAGEMENT IN THE CITY IN THE CONDITIONS OF THE PERMANENT INTENSIFICATION ROAD}

Summary: Intensive technical and technological, economic and social development, population growth, the accelerated pace of life and a number of other factors have, in addition to the benefits they provide residents, have a negative effect on the sustainable development of cities with the standpoint necessity of management and environmental protection in the city. In this context, the traffic has a special role. Besides all its good sides and positive economic and social effects, it is the most important factor that negatively affects the environment of the city. Numerous data about the inner city traffic, point to a growing influx of traffic and congestion in cities. Therefore, logically need to expand existing roads and new parking-space and that, as a rule at the expense of green areas, which with increasing noise and air pollution threatens the environment in which the most important condition for sustainable development of the city. Requires proper integrated approach to all the factors that can help in the creation and management of urban and environmental policy, which will control its operation lead to the creation of necessary conditions for the reduction of pollution which are primarily due to road traffic flows.

Keywords: Urban management, environmental management, transport, sustainable development of the city. 